\title{
Mapping in the Umanak district, central West Greenland
}

\section{T. C. R. Pulvertaft}

Publication of 1:100 000 geological maps from central West Greenland has reached a stage when five maps have been issued, and a sixth is in an advanced stage of preparation. However, until the summer of 1978 , one of the most readily accessible areas in this part of Greenland - that around and east of Umanak - had not been mapped in greater detail than required for the production of the 1:500 000 sheet Søndre Strømfjord - Nûgssuaq. Consequently it was decided that the writer, together with a group of senior students from the Institute of General Geology, Copenhagen University, should remap the area over a period of three seasons with a view to preparation of the 1:100 000 sheet 70 V.2 Nord - Agpat. This work was started in the 1978 field season when in all four geologists, each with an assistant, were in the field. The areas in which the individual geologists worked are shown in fig. 9. Mapping was carried out on enlargements of vertical aerial photographs provided by the Geodetic Institute, the 1:50000 topographic sheets being unsuitable for detailed mapping. Logistic support was provided by the GGU cutter $N$. V. Ussing, with Flemming Nielsen as skipper.

Before the new mapping began it was known that gneisses of various kinds are by far the most widespread rocks in the area. Anorthositic rocks are known to occur on Drygalskis Halvø, and on Agpat Henderson \& Pulvertaft (1967) had recorded the southernmost outcrops of marbles that could be assigned with confidence to the Marmorilik Formation. Now that it has been established that the Marmorilik Formation was deposited discordantly on the gneiss complex (Garde \& Pulvertaft, 1976), the complex structures defined by the Marmorilik Formation on Agpat take on a new significance, since they must have been superimposed on a whole set of earlier structures in the gneiss basement. Fortunately there

Fig. 9. Outline map of the Umanak district showing the individual mapping areas and the extent of the mapping achieved in 1978 (ruled). Area II: Jeppe B. Jørgensen; areas IV and VIII: T. C. R. Pulvertaft; area VI: Morten C. Andersen; area VII: J. Christian Knudsen. Area I was mapped by G. Henderson and T. C. R. Pulvertaft in 1962 and 1963.

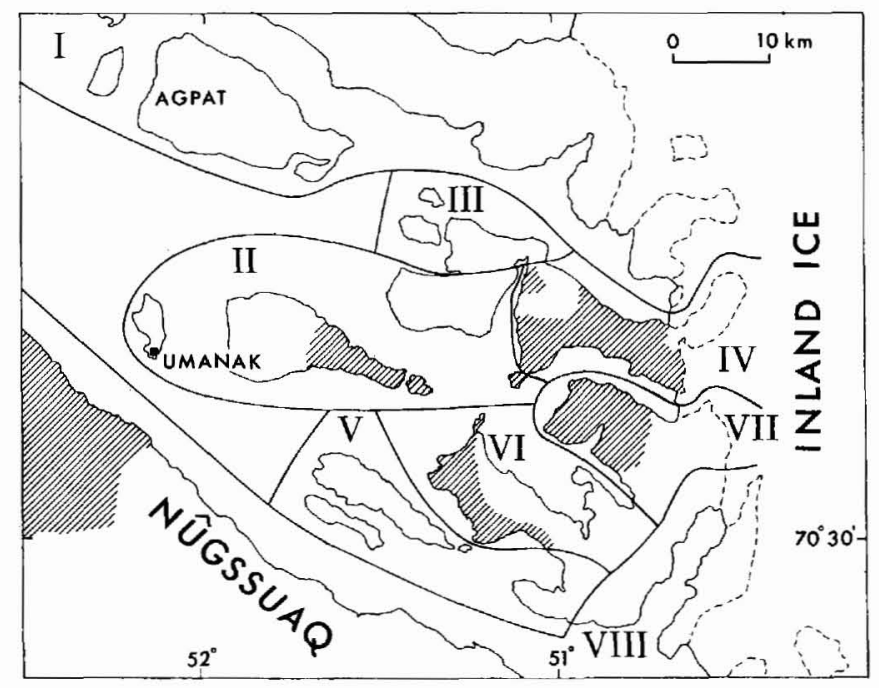


are in the gneisses a number of horizons of amphibolite, often accompanied by ultrabasic pods, and rusty brown weathering paragneiss or schist that offer a means of mapping out the complex structures.

Scattered metabasic intrusions known to occur in the area have been suggested as a means by which different phases in the structural development of the gneiss complex might be separated (Pulvertaft, 1973).

In addition to all these Precambrian rocks, which are at least $1700 \mathrm{~m}$.y. old, the Agpat 1:100 000 sheet includes small areas of Cretaceous sediments described first in the last century and more recently by Schiener (1977). Basaltic rocks of the West Greenland Tertiary province cap some of the highest mountains in the south-west part of the sheet area.

From the 1978 mapping the following comments and conclusions of general interest can be made.

Morten C. Andersen, working in the area in which the anorthositic rocks are best developed (fig. 9), found that these rocks vary in lithology from anorthosite (sensu stricto) to leucogabbro. In the latter the dark minerals (biotite and hornblende) are concentrated in aggregates which are generally, but not always, lenticular or schlieren-shaped. Parallelism of schlieren gives the rock a rough foliation. Grain-size is medium to coarse; no primary megacrysts or other primary textures have yet been observed. The anorthosite/leucogabbro throughout its outcrop is broken up into subangular to rounded lumps 1-3 m across that are tightly packed in a biotite gneiss matrix. The matrix is wrapped around the lumps and its foliation 'clings' to the surface of the lumps. The foliation in the outermost few centimetres of the lumps is also parallel to the margins of the lumps. Both the foliation in the matrix and that around the margins of the lumps are consequently discordant to the foliation within the lumps. Furthermore the latter foliation shows no parallelism nor any meaningful pattern when traced from lump to lump. Andersen interprets these relations as indicating that the anorthosite/leucogabbro has been affected by at least two phases of deformation, one prior to disruption giving rise to the internal foliation in the lumps, and one related to the disruption that rotated the lumps and deformed the outer few centimetres of the lumps. In spite of these complications the anorthosite/leucogabbro body has easily mappable boundaries. Its overall form is that of a sheet with a thickness varying from a few metres in the north-west to about $350 \mathrm{~m}$ in the south-east. The irregularities mentioned by Escher \& Pulvertaft (1976, p. 110) are due to folding and to local near-parallelism between the sheet and the topography.

In area VII (fig. 9) Christian Knudsen has found that some of the thicker (up to $100 \mathrm{~m}$ ) amphibolitic horizons have a much more varied and interesting lithology than previously realised. Apart from homogeneous and layered amphibolite \pm diopside and garnet like that anywhere in the Precambrian of West Greenland, there are some distinctive rock types such as schists rich in brown amphibole (?anthophyllite), cordierite-anthophyllite rock, and glassy quartzite sometimes with plentiful sillimanite and locally with large crystals of blue cordierite or films of green mica (?fuchsite). These lithologies recall lithologies seen in the Malene supracrustal units of the Godthåbsfjord region and elsewhere in the Archaean of southern West Greenland (Bridgwater et al., 1976, p. 41).

Structurally area VII is dominated by a large recumbent fold closing to NNE. Most of the area mapped to date lies in the lower flank of this fold, the upper flank only being preserved 
in the higher ground to the south-east. Lithologies in the amphibolitic horizons are best preserved in the hinge zone of this fold.

The east end of the island Storø east of Umanak (area II) has always attracted attention on account of the rusty ochre weathering of pyrrhotite-rich graphitic schist which Jeppe Jørgensen found to make up only 10 per cent of a $375 \mathrm{~m}$ thick unit of supracrustal biotite-garnet-sillimanite gneiss with leucocratic layering and lenses. Within this there are also thin layers of quartzite and an unusual rock consisting of thin layers of quartz alternating with seams of orthopyroxene. This unit has been termed the Akugdleq supracrustal unit. The westerly termination of the unit was found by Jørgensen to be due to an isoclinal recumbent fold closure with axial trend approximately NW. A second, almost isoclinal, recumbent fold involving the Akugdleq unit has an axis trending $105^{\circ}$. Observations on small-scale structures point to more than one phase of tight to isoclinal folding, which may account for the diverging axes of the larger folds. Present dips are largely due to later open folding such as that seen in the open syncline on eastern Storø.

With all this demonstrable complexity in the Umanak district, the very simple structural build-up of area IV is a paradox. A straightforward succession of gneiss types and amphibolites can be traced around almost the whole area. The structure is that of a slightly tilted stack of plates. Among the marker horizons in this stack are augen gneisses which on a small scale have local discordant intrusive relations yet on a large scale form continuous concordant markers, even though one such horizon is only $2-5 \mathrm{~m}$ thick. The most likely explanation of the apparent simplicity of this area is that it represents the product of the most penetrative and extensive lateral movements in the region.

As can be seen from fig. 9, mapping was also carried out in the south-west corner of the Agpat sheet area, where Cretaceous sediments and Tertiary basaltic rocks are exposed. A full report on the Cretaceous sediments is in preparation. The succession of basaltic rocks begins with $360 \mathrm{~m}$ of olivine basalt breccia and pillow lava. These lie discordantly on the tilted Cretaceous sediments and overlap onto the underlying gneisses. The dip of foresets in the mega-cross-bedded pillow lava indicates a provenance from the north-north-west. The pillow lavas and breccias are overlain by about $200 \mathrm{~m}$ of olivine basalt which is in turn overlain by thick flows of plagioclase-porphyritic basalt. There is a very gradual regional fall to the south-east in the level of the olivine basalt - plagioclase-porphyritic basalt boundary.

\section{References}

Bridgwater, D., Keto, L., McGregor, V. R. \& Myers, J. S. 1976: Archaean gneiss complex of Greenland. In Escher, A. \& Watt, W. S. (edit.) Geology of Greenland, 18-75. Copenhagen: Geol. Surv. Greenland.

Escher, A. \& Pulvertaft, T. C. R. 1976: Rinkian mobile belt of West Greenland. In Escher, A. \& Watt, W. S. (edit.) Geology of Greenland, 104-119. Copenhagen: Geol. Surv. Greenland.

Garde, A. A. \& Pulvertaft, T. C. R. 1976: Age relations of the Precambrian Marmorilik Formation, central West Greenland. Rapp. Grønlands geol. Unders. 80, 49-53.

Henderson, G. \& Pulvertaft, T. C. R. 1967: The stratigraphy and structure of the Precambrian rocks of the Umanak area, West Greenland. Meddr dansk geol. Foren. 17, 1-20.

Pulvertaft, T. C. R. 1973: Recumbent folding and flat-lying structure in the Precambrian of northern West Greenland. Phil. Trans. R. Soc. Lond. A 273, 535-545. 
Schiener, E. J. 1977: Sedimentological observations on early Cretaceous sediments in eastern parts of the Nûgssuaq embayment. Rapp. Grønlands geol. Unders. 79, 45-61.

Institut for almen Geologi, University of Copenhagen,

$\emptyset$ stervoldgade 10,

$D K-1350$ Copenhagen $K$.

\section{New investigations of Tertiary lavas and dykes in the area around Disko Fjord, South Disko, central West Greenland}

\section{Finn Ulff-Møller}

The purpose of the summer's field work was twofold: (a) to search for native iron and sulphide mineral assemblages in the northern extension of the Kitdlit dyke (Fundal, 1975; Pedersen, 1977a \& 'a' in figs $10 \& 11$ ) and other related (sediment contaminated) dykes, and (b) to map the surrounding area as a contribution to the map sheet Diskofjord ( $69 \mathrm{~V}$. 1 $\mathrm{N}$, fig. 2). About $600 \mathrm{~km}^{2}$ were mapped in detail and $1500 \mathrm{~km}^{2}$ briefly surveyed.

\section{Regional geology}

Amphibolite facies gneisses and metasediments of Precambrian age, constituting the north-south trending Disko gneiss ridge, are exposed where deep valleys transect the plateau basalts.

In places the Precambrian rocks are overlain by Cretaceous-Tertiary sediments which appear in a few exposures of arkose on the eastern flank of the gneiss ridge.

A sequence of Lower Tertiary plateau basalt rests directly on Precambrian rocks or the overlying sediments. Most basalts belong to the Rinks Dal Member of the Maligât Formation (for stratigraphical subdivision of the lava sequence see Hald \& Pedersen, 1975; Pedersen, 1975) but in the west (loc. 1, fig. 10) they are overlain by at least $160 \mathrm{~m}$ of lavas of the Nordfjord Member. Loose blocks of characteristic andesitic rocks indicate that lavas of the Niaqússat Member were present at slightly higher stratigraphical levels, being removed by later erosion. No olivine-rich lavas of the underlying Vaigat Formation have been observed. The total stratigraphic thickness of the lava sequence within the area is about 1.5 $\mathrm{km}$.

The lavas of the Rinks Dal Member form a monotonous sequence of mainly plagioclase-(olivine) glomerophyric tholeiitic basalts with subordinate amounts of aphyric or slightly plagioclase microporphyric basalts and only very few olivine-rich tholeiitic basalts. Slight differences in flow morphology and in weathering colour, visible in good light, have made it possible to trace several marker horizons over long distances. This infers considerable lateral uniformity of the lava sequence. East of the gneiss ridge the lowermost exposed lavas of the Rinks Dal Member grade into a sequence of pillow breccia. 